\title{
Forest and Forest Succession in Hong Kong, China
}

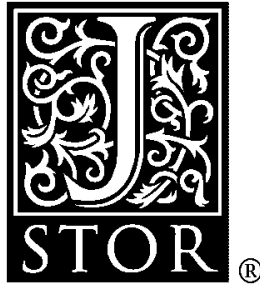

\author{
Xue Ying Zhuang; Richard T. Corlett
}

Journal of Tropical Ecology, Vol. 13, No. 6. (Nov., 1997), pp. 857-866.

Stable URL:

http://links.jstor.org/sici?sici=0266-4674\%28199711\%2913\%3A6\%3C857\%3AFAFSIH\%3E2.0.CO\%3B2-9

Journal of Tropical Ecology is currently published by Cambridge University Press.

Your use of the JSTOR archive indicates your acceptance of JSTOR's Terms and Conditions of Use, available at

http://www.jstor.org/about/terms.html. JSTOR's Terms and Conditions of Use provides, in part, that unless you have obtained prior permission, you may not download an entire issue of a journal or multiple copies of articles, and you may use content in the JSTOR archive only for your personal, non-commercial use.

Please contact the publisher regarding any further use of this work. Publisher contact information may be obtained at http://www.jstor.org/journals/cup.html.

Each copy of any part of a JSTOR transmission must contain the same copyright notice that appears on the screen or printed page of such transmission.

JSTOR is an independent not-for-profit organization dedicated to and preserving a digital archive of scholarly journals. For more information regarding JSTOR, please contact support@jstor.org. 


\title{
Forest and forest succession in Hong Kong, China
}

\author{
XUE YING ZHUANG* and RICHARD T. CORLETT $†$ \\ *College of Forestry, South China Agricultural University, Guangzhou 510642, China \\ $\dagger$ Department of Ecology $\&$ Biodiversity, University of Hong Kong, Pokfulam Road, Hong \\ Kong
}

\begin{abstract}
Hong Kong is on the northern margin of the Asian tropics. The original forest cover was cleared centuries ago but secondary forest has developed since 1945 at many sites protected from fire and cutting. There are also older forest patches maintained behind villages for reasons of 'feng shui', the Chinese system of geomancy. All plants $>2 \mathrm{~cm}$ dbh were identified and measured in forty-four 400- $\mathrm{m}^{2}$ plots. Detrended correspondence analysis showed a floristic continuum, with the montane sites $(>500 \mathrm{~m})$ most distinct and some overlap between lowland post-1945 secondary forest and the feng shui woods. The 30-40 year-old secondary forest is dominated by Persea spp. Montane forest is similar but lacks several common lowland taxa of tropical genera and includes more subtropical taxa. The feng shui woods have the most complex structure and contain some tree species not found in other forest types. Their origin and history is obscure but we suggest that both planting and selective harvesting have had a role in their current species composition
\end{abstract}

KEY WORDS: China, forest, Hong Kong, secondary forest, succession, vegetation

\section{INTRODUCTION}

Ecological studies in the tropics have been concentrated in those areas where human impact is least obvious. However, most tropical landscapes in the future will be human-dominated, with fragmented forests, degraded soils and depleted faunas. In tropical East Asia, where the majority of the biota is forestdependent, the survival of native biodiversity in such landscapes will depend largely on the resilience of this forest. The long-term survivors will be species which can persist in tiny forest remnants or disperse between regenerating patches on abandoned land (Corlett \& Turner 1997). This paper reports a study of forest and forest succession in the human-dominated landscape of Hong Kong, which has a long history of human impact and one of the highest population densities in the world $\left(6.4 \mathrm{~m}\right.$ people in $\left.1100 \mathrm{~km}^{2}\right)$, yet still suppports a tree flora of 360 native species (Zhuang et al. 1997)

\section{STUDY AREA}

Hong Kong $\left(22^{\circ} \mathrm{N}, 114^{\circ} \mathrm{E}\right)$ consists of a section of the Chinese mainland (Kowloon and the New Territories, $784 \mathrm{~km}^{2}$ ) and several islands, of which the 


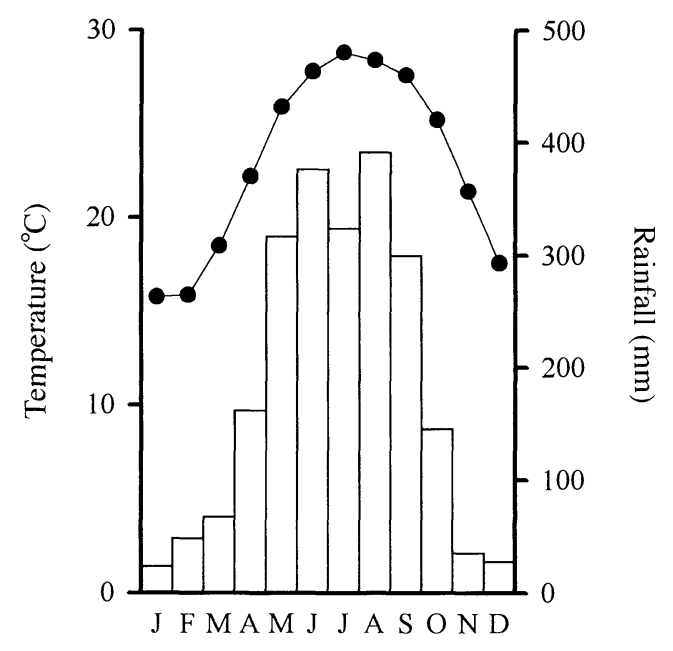

Figure 1. Monthly means of temperature (dots) and rainfall (bars) at the Royal Observatory, Kowloon (1960-1991).

largest are Lantau Island $\left(148 \mathrm{~km}^{2}\right)$ and Hong Kong Island $\left(82 \mathrm{~km}^{2}\right)$. The topography is mostly rugged with the highest point at Tai Mo Shan $(957 \mathrm{~m})$ in the New Territories. More than two-thirds of Hong Kong is underlain by volcanic rocks with most of the remainder consisting of coarse-grained granites. Both rainfall and temperature are highly seasonal (Figure 1) but the coincidence of dry and cool weather reduces the water stress experienced by plants and most woody species are evergreen. Frosts occur several times a decade above $500 \mathrm{~m}$ altitude and occasionally near sea-level in the northern New Territories (Corlett 1992). Not only is Hong Kong on the climatic margins of the tropics but Takhtajan (1986) places the boundary between the Holarctic and Palaeotropical Floral Kingdoms a few kilometres to the west. Thus the vegetation of Hong Kong is of considerable biogeographic as well as ecological interest.

Although the original vegetation of the Hong Kong region must have been evergreen or semi-evergreen forest, this was largely cleared at an unknown date (probably between 1000 and 1700 A.D.) before the start of the period of British administration (1841-1997) (Dudgeon \& Corlett 1994). Today, all flat land is urbanised, cultivated or abandoned cultivation, while the steep hill-sides are covered in fire-maintained grassland, shrubland or, locally, secondary forest. Secondary forest (in the sense of Corlett 1994) covers c. $8 \%$ of the Territory, mostly in small patches (Ashworth et al. 1993). Almost all this secondary forest has developed since 1945 , as most existing woody vegetation was cut for fuel during the Japanese Occupation (1942-1945). Most of the woodlands older than 1945 in Hong Kong are located behind villages (or abandoned village sites) where they were maintained for reasons of 'feng shui' (literally, 'wind and water'), the Chinese system of geomancy (Williams \& Webb 1994). The origin and history of these feng shui woods is obscure but some, at least, are older than the British presence in the Territory. Some small patches of 
woodland in steep upland valleys may also be of considerable age. However, there is no strong evidence that any area in the Territory has been continuously wooded since before the clearance of the primeval forest.

\section{METHODS}

Forty-four $400-\mathrm{m}^{2}$ plots (1.76 ha) were studied during 1989-92. Thirteen of these plots were in feng shui woods behind current or abandoned villages while the remaining 31 were on hillsides in the New Territories, on Lantau Island, and on Hong Kong Island. No other island bears forest. Each plot consisted of four, contiguous $10 \mathrm{~m} \times 10 \mathrm{~m}$ subplots subjectively arranged to maximise physiognomic uniformity. A larger plot size or one of constant shape would have limited the number of sites that could be sampled, given the fragmentary nature of Hong Kong's forest area. The sites were subjectively chosen for geographic spread and to maximise the range of forest types sampled. Within each plot, the diameters of all plants more than $2 \mathrm{~cm} \mathrm{dbh}$ (diameter at breast height, $1.3 \mathrm{~m}$ ) were measured and, as far as possible, all measured plants were identified. A list was made of plants less than $2 \mathrm{~cm} \mathrm{dbh}$. A minimum age for the forest at each site was estimated from old aerial photographs. The first complete aerial cover for the Territory is from 1945, the time with the minimum forest extent this century. Basal area was used as a measure of abundance of each species in each plot and the data were analyzed with detrended correspondence analysis using the CANOCO software (Ter Braak 1988). No species were excluded but the range of abundance values was compressed by logarithmic transformation, following standard practice (Gauch 1982).

\section{RESULTS}

The total tree flora $(>2 \mathrm{~cm} \mathrm{dbh})$ of the 44 plots consisted of at least 228 taxa (192 identified to the species level) in 56 families. One taxon, here referred to as Persea longipedunculata (the Machilus thunbergii of previous Hong Kong publications), almost certainly included more than one, morphologically similar species. Plant names follow Zhuang et al. (1997), which also describes the distribution and ecology of the tree species recorded in this study.

Only the feng shui wood sites were forested in the 1945 aerial photographs. The other lowland $(<500 \mathrm{~m})$ sites were grassland or shrubland, sometimes with scattered trees. Additional trees may have been present in shrub form as a result of cutting for firewood. The montane sites $(>500 \mathrm{~m})$ all supported some trees but these did not form a closed canopy. One plot (young secondary forest with an unusual abundance of Microcos paniculata and Ilex rotunda) was an outlier on the initial DCA ordination and was excluded from further analyses, following the recommendations of Ter Braak (1988). The first axis of the DCA ordination of the remaining 43 plots with 223 species separates the six sites 


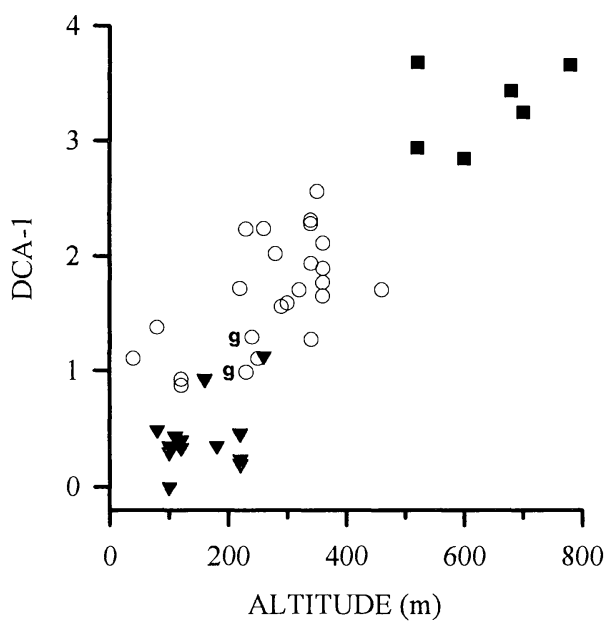

Figure 2. The relationship between scores on the first axis of the DCA ordination and altitude above sea-level for forty-three $400-\mathrm{m}^{2}$ forest plots. The plots are in feng shui woods (solid triangles), lowland secondary forest (open circles) and montane forest (solid squares). All plots are on volcanic rocks except the two on granite (labelled with ' $\mathrm{g}$ ').

located above $500 \mathrm{~m}$ altitude (hereafter called montane forest) from the lowland sites, and most of the post-1945 secondary forests from the feng shui woods, although there is some overlap (Figure 2). The first axis shows a strong relationship with altitude $\left(\mathrm{R}^{2}=74.4 \%, \mathrm{P}<0.001\right)$ but secondary forests and feng shui woods within the same altitudinal range show only a little overlap on the first DCA axis. The second axis is not shown because it had no obvious ecological interpretation and may be an artifact of the detrending procedure (Van Groenewoud 1992).

The results suggest that the sample plots are part of a floristic continuum which cannot be divided on floristic grounds alone. However, the convenient and logical division into three basic forest types - feng shui woods, lowland secondary forests, and montane forests - on the basis of site history and elevation, does not conflict with the floristic information and is adopted here. The composition and structure of these three major forest types are summarised in Tables 1 and 2 and are described separately below.

\section{Lowland secondary forest}

This forest type accounts for most of the natural forest in Hong Kong. The sites examined ranged from $40-460 \mathrm{~m}$ altitude but small patches of similar species composition occur from near sea-level up to about $500 \mathrm{~m}$. This forest has developed on areas protected from fire and other disturbance since 1945. Most sites were more or less steeply sloping with a variable amount of rock exposed at the surface. Although granite underlies approximately $25 \%$ of the Territory, it supports very little forest. The two plots on granite were not floristically distinct from the others on volcanic rocks (Figure 2). Typically this 
Table 1. Tree family dominance in Hong Kong forests: mean percentage of total basal area and total number of species recorded in lowland secondary forest (25 plots summing to 1 ha in area), feng shui woods (13 plots, $0.52 \mathrm{ha}$ ), and montane forest (6 plots, $0.24 \mathrm{ha}$ ).

\begin{tabular}{lcccccc}
\hline & \multicolumn{2}{c}{ Lowland secondary } & \multicolumn{2}{c}{ Feng shui } & \multicolumn{2}{c}{ Montane } \\
\cline { 2 - 7 } Family & $\begin{array}{c}\text { basal } \\
\text { area (\%) }\end{array}$ & $\begin{array}{c}\text { no. of } \\
\text { species }\end{array}$ & $\begin{array}{c}\text { basal } \\
\text { area (\%) }\end{array}$ & $\begin{array}{c}\text { no. of } \\
\text { species }\end{array}$ & $\begin{array}{c}\text { basal } \\
\text { area (\%) }\end{array}$ & $\begin{array}{c}\text { no. of } \\
\text { species }\end{array}$ \\
\hline Aquifoliaceae & 2.1 & 7 & 0.4 & 7 & 4.8 & 5 \\
Araliaceae & 5.0 & 2 & 1.3 & 2 & 4.0 & 2 \\
Elaeocarpaceae & 0.4 & 4 & 3.7 & 4 & 6.4 & 3 \\
Euphorbiaceae & 3.3 & 6 & 15.8 & 14 & 0.0 & 0 \\
Fagaceae & 1.4 & 2 & 4.1 & 6 & 6.9 & 4 \\
Lauraceae & 53.2 & 9 & 18.5 & 14 & 37.3 & 6 \\
Moraceae & 0.9 & 7 & 2.4 & 11 & 0.7 & 3 \\
Myrsinaceae & 1.1 & 2 & 0.2 & 3 & 6.6 & 1 \\
Myrtaceae & 0.8 & 3 & 1.7 & 7 & 0.7 & 1 \\
Rosaceae & 2.3 & 3 & 10.5 & 4 & 2.2 & 2 \\
Rubiaceae & 1.5 & 6 & 3.9 & 9 & 0.7 & 2 \\
Symplocaceae & 1.8 & 2 & 1.5 & 2 & 6.5 & 4 \\
Theaceae & 8.4 & 8 & 11.0 & 5 & 5.6 & 8 \\
\hline
\end{tabular}

Table 2. Structural characteristics of lowland secondary forest, feng shui woods, and montane forest in Hong Kong. Values are means per $400-\mathrm{m}^{2}$ plot (and ranges).

\begin{tabular}{lccc}
\hline & Lowland & Feng shui & Montane \\
\hline Spp. $>2 \mathrm{~cm} \mathrm{dbh}$ & $27(16-45)$ & $32(15-41)$ & $26(20-31)$ \\
Trees $>2 \mathrm{~cm} \mathrm{dbh}$ & $172(94-374)$ & $156(107-221)$ & $157(68-232)$ \\
Stems $>2 \mathrm{~cm} \mathrm{dbh}$ & $216(115-509)$ & $180(119-248)$ & $229(105-302)$ \\
Stems per tree & 1.25 & 1.15 & 1.48 \\
Basal area $\left(\mathrm{m}^{2}\right)$ & 1.33 & 1.66 & 1.00 \\
\hline
\end{tabular}

forest type had an even, single-layered canopy at 10-15 m, dominated by Persea longipedunculata and/or $P$. breviflora, which together usually contributed more than half the total basal area. Other common canopy species were Acronychia pedunculata and Schefflera octophylla. The understorey was dominated by Psychotria rubra, Symplocos spp., and Ardisia quinquegona. Saplings of the canopy species were rare or absent. Many trees were multi-trunked, suggesting an origin by coppicing, possibly from individuals which survived cutting for fuel during 1941-45.

The earlier stages of succession were too dense and impenetrable for quantitative study. Qualitative observations showed that the secondary forest canopy-dominants currently invade fire-protected grassland at the same time as a variety of light-demanding shrub species, of which the most abundant is Rhodomyrtus tomentosa. The youngest secondary forest plots studied were distinguished by the presence of these light-demanding shrubs which are eliminated when a closed tree canopy is formed.

\section{Feng shui woods}

Feng shui woods are defined here by their location behind current or abandoned villages. They are structurally and floristically very variable and only 
large (2-14 ha), 'natural-looking', woods with little evidence of recent disturbance were sampled. The sites examined ranged from $80-220 \mathrm{~m}$ altitude on Hong Kong Island and in the New Territories. Characteristic structural features in the plots studied included a multi-layered canopy, the presence of large trees $(>22.5 \mathrm{dbh})$ and the occurrence of large woody lianes. The apparently oldest and best-developed woods had an upper canopy at 15-25 m dominated by Endospermum chinense, Pygeum topengii, or Schima superba, and a subcanopy at 10-15 m of Sarcosperma laurinum, Sterculia lanceolata and Cryptocarya spp. The commonest understorey species were Psychotria rubra, Lasianthus spp. and Memecylon spp. Woody lianes were common and included Ampelopsis cantoniensis, Gnetum montanum and Strychnos spp. Other feng shui woods, however, which had apparently suffered serious damage during the Japanese occupation, were more similar in species composition to the lowland secondary forest described above.

\section{Montane forest}

This forest type is confined to upland valleys above $500-550 \mathrm{~m}$. Areas large enough to sample were found only on Tai Mo Shan, in the New Territories, and Sunset Peak, on Lantau Island, although small patches occur on other peaks. Most sites were steeply sloping and much of the ground was covered in exposed rock and boulders. The canopy at $c .10 \mathrm{~m}$ was dominated by a Persea similar to Persea longipedunculata and by $P$. breviflora, as in the lowland secondary forest. However, variation in leaf damage after a severe frost, with correlated morphological differences, suggests that what we have called Persea longipedunculata included a strictly montane Persea as well as the lowland species. Recognition of this taxon would have increased the floristic distinctiveness of the montane forest. All plots also included some very large trees of various species that must have been older than the surrounding forest. These trees - presumably the ones visible in the 1945 aerial photographs - are probably relicts of the previous forest cover. This forest type also had the highest proportion of multitrunked trees, suggesting coppicing after cutting. In comparison with the lowland secondary forest, there were more stems $<15 \mathrm{~cm} \mathrm{dbh}$. The commonest smaller species were Myrsine neriffolia, Elaeocarpus spp., and Camellia spp. The understorey was usually dominated by Camellia spp., Eurya spp. and Ilex spp. The most distinctive feature of the montane forest is the complete absence of several very common lowland taxa, including Acronychia pedunculata, Aporosa dioica, Ardisia quinquegona and Psychotria rubra. On Tai Mo Shan, the lowlandmontane floristic transition occurs at 500-550 m.

\section{DISCUSSION}

Hong Kong's long and complex, but largely unrecorded, history of human impact (Corlett \& Turner 1997, Dudgeon \& Corlett 1994) makes interpretation of the present vegetation difficult. An additional, recent complication has been the virtual elimination of Pinus massoniana by the introduced pine wood nematode (Bursaphelencus xylophilus (Steiner \& Buhrer) Nickle) in the past decade. 
Much of the present lowland secondary forest developed initially under a canopy of planted, broadcast or spontaneous pine but we have no evidence that the absence of the pine has significantly changed the course of secondary succession.

The majority of the forest in Hong Kong is less than $50 \mathrm{y}$ old and the canopy is still dominated by more or less light-demanding tree species. Tree growth rates, in terms of height increment, are similar to those observed on highlydegraded sites in equatorial Singapore (Corlett 1991) and both growth rates and species turnover on lowland sites with deeper, more fertile soil would presumably be more rapid. Potentially-large, shade-tolerant tree species are rare in the lowland secondary forest but seedlings and saplings of Sarcosperma laurinum and Cryptocarya chinensis occur in some of the older forest sites. The only forests older than 1945 below $500 \mathrm{~m}$ in Hong Kong are feng shui woods. The relationship between the feng shui woods and lowland secondary forest is problematical. The DCA analysis shows that the feng shui woods form part of a floristic continuum with the older lowland secondary forest. However, this does not necessarily indicate that they developed from this type of forest by succession: i.e. the floristic continuum is not necessarily a successional continuum. The overlap between the two types could also be explained by the degradation of feng shui woods by cutting or hill fires, leading to invasion by lightdemanding species more characteristic of younger forest.

There are three extreme possibilities for the origin of feng shui woods: as preserved remnants of the original forest cover of Hong Kong, by natural succession, or by planting. The first possibility is not supported by the current floristic composition of these woods in comparison with what is known about the primeval forest cover (see below), although this may just be the result of centuries of disturbance. Even in what appear to be the oldest woods the canopy is dominated by shade-intolerant species, suggesting that they are far from floristic equilibrium. However, the second possibility, by itself, seems unlikely: undisturbed forest succession is not likely to occur adjacent to an active village. If they did originate by succession, however, the early stages need not necessarily have resembled the lowland secondary forest of today. The feng shui woods included in this study are mostly at lower altitude and on less badly-eroded sites, where forest succession may have followed a different pathway in the early stages. The third possibility is probably at least partly true: there are undoubted planted trees (such as Cinnamomum camphora and various exotic fruit trees) in most feng shui woods, although these were avoided during siting of sample plots, and many, which were not included in this study, consist largely of planted trees. We suggest that the most probable origin for the well-developed feng shui woods described in this study is a combination of planting, particularly of attractive or economically important tree species, natural invasion by other trees and shrubs, and selective harvesting for timber, firewood and other products.

Although feng shui woods were once found throughout South China, relatively few have survived there and they seem to have have been little studied. 
Similar 'sacred groves' - patches of forest retained or established for religious reasons - are common throughout southern and southeastern Asia and seem to have a wide range of origins (Chandrakanth \& Romm 1991, Gadgil \& Vartak 1976). As was the case with Hong Kong's feng shui woods until the last few decades, these sacred groves are often the only remaining forest in an otherwise treeless landscape.

In all forest types in Hong Kong, the forest dominants are well-dispersed by the existing vertebrate fauna (Corlett 1996). The future course of succession is likely to be controlled to a large extent by the availability of seed sources and of dispersal agents among Hong Kong's severely depleted fauna (Dudgeon \& Corlett 1994). Under-dispersal of the tree flora is probably a general feature of succession in human-dominated tropical landscapes (Corlett 1991, 1995). One tree family which is certainly under-dispersed under current conditions in Hong Kong is the Fagaceae, the largest tree family, with 33 species, mostly with a very restricted distribution. Today the Fagaceae are most prominent in the montane forest, where the original forest may not have been completely cleared, but an archaeological excavation at a coastal site on northeast Lantau Island found many fruits of Castanopsis, Lithocarpus and Quercus, dated at approximately 6000 y B.P. (R. T. Corlett \& X. Zhuang unpubl. data). The relative shade tolerance of many species (X. Zhuang unpubl. data) also argues for a prominent role for the Fagaceae in the original forest cover of the region. Perhaps significantly, although the Fagaceae are absent from most existing feng shui woods, they were common in a lowland woodland at Happy Valley on Hong Kong Island which was a major collecting site for nineteenth century botanists (e.g. Bentham 1861) but was cleared about a century ago.

Unfortunately, the vegetation of adjacent areas of South China has had a similar history of intense human impact and there are no definite remnants of the primary lowland forest. The best preserved forest area is at Ding Hu Shan Biosphere Reserve $\left(23^{\circ} \mathrm{N}, 112^{\circ} \mathrm{E}\right), 190 \mathrm{~km}$ northwest of Hong Kong. This reserve contains 266 ha of forest preserved next to a temple and believed to be at least $400 \mathrm{y}$ old. This forest has a similar species composition to the bestdeveloped feng shui woods in Hong Kong, except that huge individuals of Castanopsis chinensis dominate the canopy and Endospermum is absent (Wang et al. 1982).

The biogeographical interest of Hong Kong's forests lies in the transitional nature of the flora. The strong relationship between floristic composition and altitude suggests a dominant role for some aspect of temperature. Hong Kong's flora entirely lacks the strictly tropical families Dipterocarpaceae and Myristicaceae, although both these families occur at similar latitudes in south-west China. However, the Annonaceae, Apocynaceae, Euphorbiaceae, Guttiferae, Moraceae, Rubiaceae and Sterculiaceae are all represented in the lowland forest flora of Hong Kong by tropical genera and are particularly prominent in the feng shui woods. In contrast, the montane forest flora consists largely of subtropical (or tropical montane) genera. The Annonaceae and Euphorbiaceae 
are absent and the Moraceae and Rubiaceae are greatly reduced in diversity. The upper limit of the lowland flora seems to be set by frost frequency. Frosts occur above $c .500 \mathrm{~m}$ at least once a decade and cause most damage to species in predominantly tropical lowland genera (Corlett 1992). Chilling temperatures and less frequent frosts below this altitude may be sufficient to exclude the most sensitive tropical taxa from even the lowland flora.

Although Hong Kong must have been entirely forested in the past, the surviving fauna has few, if any, forest specialists (Corlett \& Turner 1997, Dudgeon \& Corlett 1994). Even squirrels were absent until recently, although Callosciurus flavimanus was introduced in the 1970s and is now widespread. This suggests that deforestation was near complete, with the surprisingly rich tree flora (360 spp., Zhuang et al. 1997) surviving in feng shui woods, and as tiny patches and isolated trees in topographically-protected sites. Increasing forest area over the last $20 \mathrm{y}$ has allowed several new forest bird (Kwok \& Corlett 1998) and butterfly (Bascombe 1995) species to become established (most, probably, re-established), but the isolation of Hong Kong's forest areas from the larger remnants to the north must put limits on this process. This suggests that reforestation may have relatively little conservation benefit without the active reintroduction of the forest fauna. Unfortunately, much of the original fauna of South China is now regionally extinct.

\section{ACKNOWLEDGEMENTS}

Zhuang Xue Ying was supported during this study by a Rockefeller Brothers Fund Postgraduate Scholarship. We wish to acknowledge the assistance provided by the Directors and staff of the Kadoorie Agricultural Research Centre and the Agriculture and Fisheries Department. We also wish to thank S. T. Chan, Lawrence Chau, D. A. Griffiths and other staff and students of the Department of Botany for their help and advice. In addition, we are grateful to Professors Lu Yonggen, Pang Xiongfei, Lo Shiming and Li Pingtao of the South China Agricultural University for their continued support and encouragement.

\section{LITERATURE CITED}

ASHWORTH, J. M., CORLETT, R. T., DUDGEON, D., MELVILLE, D. S. \& TANG, W. S. M. 1993. Hong Kong flora and fauna: computing conservation. Worldwide Fund for Nature, Hong Kong. 24 pp.

BASCOMBE, M. J. 1995. Checklist of the butterflies of South China. Memoirs of the Hong Kong Natural History Society 20:1-205.

BENTHAM, G. 1861. Flora Hongkongensis. Lovell Reeve, London. 482 pp.

CHANDRAKANTH, M. G. \& ROMM, J. 1991. Sacred forests, secular forest policies and people's actions. Natural Resources Journal 31:741-756.

CORLETT, R. T. 1991. Plant succession on degraded land in Singapore. Journal of Tropical Forest Science $4: 151-161$.

CORLETT, R. T. 1992. The impact of cold and frost on terrestrial vegetation in Hong Kong. Memoirs of the Hong Kong Natural History Society 19:133-135.

CORLETT, R. T. 1994. What is secondary forest? Journal of Tropical Ecology 10:445-447.

CORLETT, R. T. 1995. Tropical secondary forests. Progress in Physical Geography 19:159-172. 
CORLETT, R. T. 1996. Gharacteristics of vertebrate-dispersed fruits in Hong Kong. Journal of Tropical Ecology 12:819-833.

CORLETT, R. T. \& TURNER, I. M. 1997. Long-term survival in tropical forest remnants in Singapore and Hong Kong. Pp. 333-345 in Laurance, W. F. \& Bierregaard, R. O. (eds). Tropical forest remnants: ecology, management and conservation of fragmented communities. Chicago University Press, Chicago.

DUDGEON, D. \& CORLETT, R. T. 1994. Hills and streams: an ecology of Hong Kong. Hong Kong University Press, Hong Kong. 234 pp.

GADGIL, M. \& VARTAK, V. D. 1976. The sacred groves of Western Ghats in India. Economic Botany 30:152-160.

GAUCH, H. G. 1982. Multivariate analysis in community ecology. Cambridge University Press, Cambridge. 298 pp.

KWOK, H. K. \& CORLETT, R. T. 1998. Seasonality of a forest bird community in Hong Kong, South China. Ibis, in press.

TAKHTAJAN, A. L. 1986. Floristic regions of the world. University of California Press, USA. 522 pp.

TER BRAAK, G. J. F. 1988. CANOCO. Agricultural Mathematics Group, Wageningen University, Netherlands. $95 \mathrm{pp}$.

VAN GROENEWOUD, H. 1992. The robustness of correspondence, detrended correspondence, and TWINSPAN analysis. Journal of Vegetation Science 3:239-246.

WANG, Z. H., HE, D. Q., SONG, S. D., CHEN, S. P., CHEN, D. R. \& TU, M. Z. 1982. The vegetation of Dinghushan Biosphere Reserve. Tropical and Subtropical Forest Ecosystem 1:77-141. (In Chinese).

WILLIAMS, M. \& WEBB, R. 1994. Rural landscapes. Pp. 113-127 in Williams, M. (ed.). The green dragon: Hong Kong's living environment. Green Dragon Publishing, Hong Kong.

ZHUANG, X. Y., XING, F. W. \& CORLETT, R. T. 1997. The tree flora of Hong Kong: distribution and status. Memoirs of the Hong Kong Natural History Society 21:

Accepted 31 May 1997 